\title{
Competitive adsorption of metal ions onto goethite-humic acid-modified kaolinite clay
}

\author{
E. I. Unuabonah ${ }^{1}$ - B. I. Olu-Owolabi ${ }^{2}$ K. O. Adebowale ${ }^{2}$
}

Received: 29 December 2014/Revised: 19 November 2015/Accepted: 11 January 2016/Published online: 4 February 2016

(C) Islamic Azad University (IAU) 2016

\begin{abstract}
A binary mixture of humic acid and geothite was prepared and used to modify kaolinite to produce geothite-humic acid (GHA)-modified kaolinite adsorbent useful for the adsorption of $\mathrm{Pb}^{2+}, \mathrm{Cd}^{2+}, \mathrm{Zn}^{2+}, \mathrm{Ni}^{2+}$ and $\mathrm{Cu}^{2+}$ from Single and Quinary (5) metal ion systems. The cation exchange capacity (CEC) and specific surface area of GHA-modified kaolinite clay adsorbent were found to be $40 \mathrm{meq} / 100 \mathrm{~g}$ and $13 \mathrm{~m}^{2} / \mathrm{g}$, respectively, with the CEC being five times that of raw kaolinite clay $(7.81 \mathrm{meq} /$ $100 \mathrm{~g}$ ). The Langmuir-Freundlich equilibrium isotherm model gave better fit to experimental data as compared with other isotherm models. In Quinary metal ion system, the presence of $\mathrm{Zn}^{2+}$ and $\mathrm{Cu}^{2+}$ appears to have an antagonistic effect on the adsorption of $\mathrm{Pb}^{2+}, \mathrm{Cd}^{2+}$ and $\mathrm{Ni}^{2+}$, while the presence of $\mathrm{Pb}^{2+}, \mathrm{Cd}^{2+}$ and $\mathrm{Ni}^{2+}$ shows a synergistic effect on the adsorption of $\mathrm{Zn}^{2+}$ and $\mathrm{Cu}^{2+}$. The GHA-modified kaolinite showed strong preference for the adsorption of $\mathrm{Pb}^{2+}$ in both metal ion systems. BrouersWeron-Sotolongo (BWS) kinetic model gave better fit to kinetic data compared with other kinetic models used. Data from BWS kinetic model indicate that adsorption of metal ions onto GHA-modified adsorbent in both metal ion systems followed strictly, diffusion-controlled mechanism
\end{abstract}

Electronic supplementary material The online version of this article (doi:10.1007/s13762-016-0938-y) contains supplementary material, which is available to authorized users.

B. I. Olu-Owolabi

iromidayobamidele@yahoo.co.uk

1 Environmental and Chemical Processes Research Laboratory, Department of Chemical Sciences, Redeemer's University, Ede PMB 230, Osun State, Nigeria

2 Department of Chemistry, Faculty of Sciences, University of Ibadan, Ibadan, Nigeria with adsorption reaction proceeding to $50 \%$ equilibrium in $<2 \min$ in the Single metal ion system and $<1 \mathrm{~min}$ in the Quinary metal ion system. Adsorption of metal ions onto GHA-modified kaolinite is fairly spontaneous and endothermic in nature in both metal ion systems although the rate of metal ion uptake and spontaneity of reaction are reduced in the Quinary metal ion system.

Keywords Competitive adsorption - Kaolinite - Goethite · Humic acid · Diffusion-controlled transport - Kinetics

\section{Introduction}

In natural systems, the bioavailability of heavy metal ions is largely controlled by adsorption-desorption reactions at the particle interface (Backes et al. 1995). Natural systems are composed of a heterogeneous mixture of mineral and organic solid phases as well as lots of organic and inorganic solutes that compete with heavy metal ions for adsorption sites on solids. The toxicity or bioavailability of these toxic heavy metal ions depends on their activities in solution (Buffle 1985; McBride 1994), and their migration to the biosphere depends on their speciation in the soil and aquatic systems (Choppin 1992; McCarthy et al. 1998).

Humic acid is from humic substances (HSs) found in soil organic matter. The interaction of HS (Saada et al. 2003; Wang and Xing 2005; Alekseeva and Zolotareva 2013) and goethite (Grossi and Sparks 1994; Jung et al. 1998; Lackovic et al. 2003; Gimenez et al. 2007) with clays has been well studied. Wang and Xing (2005) pointed out in their study that the aliphatic fraction of humic acid is preferentially adsorbed by clay minerals, while the aromatic fractions are left in solution. There are also reports on the separate use of humic acid, goethite, humic acid- 
modified and goethite-modified clay minerals in the immobilization of heavy metal ions (Plavsic et al. 1991; Hiraide 1992; Apak 2002; Tipping et al. 2002; Glover II et al. 2002; Wu et al. 2002; Salman et al. 2007; OluOwolabi et al. 2010).

Although we have initially reported the use of a binary mixture of geothite and humic acid for the modification of bentonite (Olu-Owolabi et al. 2010), yet no detailed report exists on the impact of some operational variables on the efficiency of a pre-adsorbed humic acid + goethite-modified clay in immobilizing heavy metal ions from aqueous systems. Furthermore, the influence of this kind of modification on the kinetic parameters of the adsorption process especially in multi-metal ion system is not yet reported even though it has been reported that the reactive edge sites of kaolinite may be coated with adsorbed organic matter (Davies 1982), further enhancing its adsorption capacity for metal ions. Clay particles coated with organics such as humic acid and goethite may find an important application in determining the environmental behavior of various ions (Takahashi et al. 1999) especially in soil systems.

It is in our opinion that a study on the influence of several variables such as $\mathrm{pH}$, adsorbent dose and temperature on the adsorption of a multi-metal ion system will provide better understanding of how clay mineral surfaces pre-modified with a binary mixture of geothite and humic acid will influence the mobility of these toxic heavy metal ions in aqueous media especially when it exists as a sediment in a water body. It is therefore the aim of this study to consider how these variables control the mobility of the simultaneous presence of $\mathrm{Ni}^{2+}, \mathrm{Cu}^{2+}, \mathrm{Zn}^{2+}, \mathrm{Cd}^{2+}$ and $\mathrm{Pb}^{2+}$ in aqueous media through a geothite-humic acidmodified kaolinite.

Kaolinite clay was chosen in this study because it is an abundant clay mineral in Nigeria (Aliyu et al. 1996). Equilibrium data obtained from the multi-metal ion system were fitted to Langmuir, Freundlich, two-site Langmuir and Langmuir-Freundlich equilibrium adsorption models, while kinetic data were fitted to pseudo-first-order (PFOM), pseudo-second-order (PSOM), Elovich, double chemisorption and the Brouers-Weron-Sotolongo (BWS) fractal kinetic models.

\section{Materials and methods}

\section{Preparation of adsorbate solutions}

All chemicals used were analytical grade and were used without further purification. Stock solutions of $\mathrm{Pb}^{2+}, \mathrm{Cd}^{2+}$, $\mathrm{Ni}^{2+}, \mathrm{Cu}^{2+}$ and $\mathrm{Zn}^{2+}$ ions were prepared by dissolving a weighed amount of their nitrate salts in deionized water and made up to mark in appropriate standard 1-L standard flask. Test solutions of heavy metal ions for the Single system adsorption were prepared using the standard dilution method in a concentration range of $5-100 \mathrm{mg} / \mathrm{L}$. In preparing multi-metal ion stock solution, the amounts of nitrate salts of all the five metal ions required for a particular concentration were weighed into a standard flask $(1 \mathrm{~L})$ in equimolar ratio and dissolved with deionized water. The solution was then made up to the mark.

\section{Preparation of adsorbent}

Kaolinite clay obtained from Federal Industrial Research Oshodi (FIRO) with source from Kankari deposit (Maradi, Niger State) was purified according to method described by Adebowale et al. (2005). The humic acid used for modification was extracted from soil using the International Humic Substance Standard (IHSS) method (Swift 1996). Fifty grams of $5 \%$ goethite-humic acid-modified kaolinite clay was prepared by suspending accurately weighed $2.5 \mathrm{~g}$ each of goethite and humic acid in $250 \mathrm{~mL} 0.01 \mathrm{M} \mathrm{NaNO}_{3}$ solution in a plastic container. Forty-five grams of kaolinite clay sample was then added to form slurry. This was tightly covered and kept at room temperature $\left(25^{\circ} \mathrm{C}\right)$ for 5 days to age. After aging, the sample was dried at $50{ }^{\circ} \mathrm{C}$, pulverized and sieved through $20-\mu \mathrm{m}$ sieve. Five percent goethitehumic acid mixture was used for modification based on our previous study (Olu-Owolabi et al. 2010). The modified kaolinite produced is now referred to as GHA-modified kaolinite clay adsorbent.

\section{Measurement of physicochemical properties of adsorbent}

The cation exchange capacity of the adsorbents was determined using the modified ammonium acetate method (Chapman 1965), while specific surface area of samples was estimated using the Sear's method (Sears 1956). The Fourier transform infrared spectroscopy was used to characterize the chemical functionalities on the surface of the adsorbents.

\section{Contact time studies}

One hundred milligrams $(0.1 \mathrm{~g})$ of GHA-modified kaolinite clay adsorbent was added to $10 \mathrm{~mL}$ of $100 \mathrm{mg} / \mathrm{L}$ metal ion solutions of each cation in 50-mL capped polyethylene bottles and agitated on a rotary shaker at constant speed of $150 \mathrm{rpm}$. Samples were withdrawn at specified time intervals and filtered with the Whatman filter paper, and filtrates were analyzed for various metal ions using a flame atomic absorption spectrometer (FAAS). Results obtained suggested that maximum adsorption was obtained at $\approx 360 \mathrm{~min}$ $(5 \mathrm{~h})$ for Single metal system and $\approx 120 \mathrm{~min}(2 \mathrm{~h})$ for Quinary metal system (Figs. A1 and A2, Appendix 1, 
Supplementary document). In further experiments carried out in this study, these equilibrium times were used.

\section{Adsorption studies}

\section{Effects of solution $\mathrm{pH}$}

This was investigated using solutions containing $100 \mathrm{mg} / \mathrm{l}$ of metal ions. One hundred milligrams $(0.1 \mathrm{~g})$ of GHAmodified kaolinite clay adsorbent was added to $10 \mathrm{~mL}$ of $100 \mathrm{mg} / \mathrm{L}$ of each metal solution of $\mathrm{Ni}^{2+}, \mathrm{Cu}^{2+}, \mathrm{Zn}^{2+}$, $\mathrm{Cd}^{2+}$ and $\mathrm{Pb}^{2+}$ in 50-mL capped polyethylene bottles, and $\mathrm{pH}$ of solutions was adjusted between 3.0-9.0 (as desired) at room temperature $(303 \mathrm{~K})$ using either $0.1 \mathrm{M} \mathrm{NaOH}$ or $0.1 \mathrm{M} \mathrm{HNO}_{3}$. Similar preparations were used for Quinary metal ion system with $0.25 \mathrm{~g}$ of GHA-modified kaolinite clay in $25 \mathrm{~mL}$ solutions containing a $100 \mathrm{mg} / \mathrm{L}$ of each metal ion. The suspensions were agitated at $150 \mathrm{rpm}$ for $5 \mathrm{~h}$ at $303 \mathrm{~K}$. The solutions were filtered using Whatman filter paper, and the concentration of metal ions in the filtrate measured using flame atomic absorption spectrophotometry (FAAS).

\section{Effects of adsorbent dose}

Batch sorption tests were carried out using various weights of GHA-modified kaolinite clay adsorbent $(0.05-1 \mathrm{~g})$ in $10 \mathrm{~mL}$ solutions with $100 \mathrm{mg} / \mathrm{L}$ of metal ions in $50-\mathrm{mL}$ capped polyethylene bottles. The suspensions were adjusted to $\mathrm{pH} 5.5$ with either $0.1 \mathrm{M} \mathrm{NaOH}$ or $\mathrm{HCl}$. Similar preparations were used for Quinary metal ion system with $0.25 \mathrm{~g}$ of GHA-modified kaolinite clay in $25 \mathrm{~mL}$ solutions containing a $100 \mathrm{mg} / \mathrm{L}$ of each metal ion. The suspensions were agitated at $150 \mathrm{rpm}$ for $5 \mathrm{~h}$ at $303 \mathrm{~K}$. The suspensions were filtered and the filtrate analyzed for the various metal ions using FAAS.

\section{Effects of temperature}

The effect of temperature was studied using four different temperatures of $303 \mathrm{~K}, 313 \mathrm{~K}, 323 \mathrm{~K}$ and $333 \mathrm{~K}$. Batch experiment was carried out with $0.1 \mathrm{~g}$ of the GHA-modified kaolinite clay adsorbent in $10 \mathrm{~mL}$ solutions of $100 \mathrm{mg} /$ $\mathrm{L}$ of each metal ion in 50-mL capped polyethylene bottles at these temperatures and at $\mathrm{pH} 5.5$ (for Single metal ion system). Similar preparations were used for Quinary metal ion system with $0.25 \mathrm{~g}$ of GHA-modified kaolinite clay in $25 \mathrm{~mL}$ solutions containing a $100 \mathrm{mg} / \mathrm{L}$ of each metal ion. The suspensions were agitated at $150 \mathrm{rpm}$ for $5 \mathrm{~h}$ at various specified temperatures. Samples were agitated at a constant speed of $150 \mathrm{rpm}$ in a thermostated water bath shaker for $5 \mathrm{~h}$. The suspensions were then filtered and the filtrate analyzed for metal ion concentration using FAAS.
The thermodynamic parameters, $\Delta H^{\mathrm{o}}, \Delta S^{\mathrm{o}}$ and $\Delta G^{\mathrm{o}}$, for the adsorption process are calculated using the relation;

$\ln \frac{C_{\mathrm{e}}}{q_{\mathrm{e}}}=\frac{\Delta S_{\mathrm{ad}}}{R}-\frac{\Delta H_{\mathrm{ad}}}{R T}$

where $C_{\mathrm{e}}$ and $q_{\mathrm{e}}$ are the equilibrium concentration (mg/L) and amount adsorbed $(\mathrm{mg} / \mathrm{L})$ and $\Delta G_{\text {ads }}, \Delta H_{\text {ads }}$ and $\Delta S_{\text {ads }}$ are the thermodynamic parameters for change in Gibbs free energy, heat and entropy, respectively. The plot of $\ln \frac{C_{\mathrm{e}}}{q_{\mathrm{e}}}$ versus $\frac{1}{T}$ yields straight lines with the slope and the intercept giving values of $\Delta H_{\text {ads }}$ and $\Delta S_{\text {ads. }}$. These values could be used to compute $\Delta G_{\text {ads }}$ from the Gibbs relation, at constant temperature $\left(\Delta G_{\text {ads }}=\Delta H_{\text {ads }}-T \Delta S_{\text {ads }}\right)$. In deriving the values of the thermodynamic parameters, it is assumed that the enthalpy does not change with temperature.

\section{Equilibrium studies}

Equilibrium experiments were carried out by adding $0.1 \mathrm{~g}$ of GHA-modified kaolinite clay adsorbent to $10 \mathrm{~mL}$ solutions with different initial metal ion concentrations ranging from 5 to $100 \mathrm{mg} / \mathrm{L}$ for each metal ion (Single metal system). Similar preparations were carried out for Quinary metal ion system with $0.25 \mathrm{~g}$ of GHA-modified kaolinite clay in $25 \mathrm{~mL}$ solutions containing similar metal ion concentration in the range of $5-100 \mathrm{mg} / \mathrm{L}$. The suspensions were agitated at $150 \mathrm{rpm}$ for $5 \mathrm{~h}$, and the temperature maintained at $303 \mathrm{~K}$. Solution (Single or multi-metal ion solutions) $\mathrm{pHs}$ were adjusted to $\mathrm{pH} 5.5$ at room temperature $(303 \mathrm{~K})$ using either $0.1 \mathrm{M} \mathrm{NaOH}$ or $0.1 \mathrm{M} \mathrm{HNO}_{3}$. The suspensions were filtered, and the concentration of metal ions in the solution was determined using flame atomic absorption spectrometry (FAAS).

\section{Kinetic studies}

Hundred milligrams of modified sample was added to $10 \mathrm{~mL}$ of $100 \mathrm{mg} / \mathrm{L}$ of metal ion in $50-\mathrm{mL}$ capped polyethylene bottles (Single metal system). Similar preparations were used for Quinary metal ion system with $0.25 \mathrm{~g}$ of GHA-modified kaolinite clay in $25 \mathrm{~mL}$ solutions containing a $100 \mathrm{mg} / \mathrm{L}$ of each metal ion. The suspensions were agitated at $150 \mathrm{rpm}$ for $5 \mathrm{~h}$ at $303 \mathrm{~K}$. These samples were withdrawn at specified time intervals. The solutions were filtered using Whatman filter paper and the concentration of metal ions in the filtrate measured using flame atomic absorption spectrophotometry (FAAS).

All experiments were carried out in duplicates. The amount of each metal ion adsorbed by the adsorbent was calculated by difference using the equation below: 
$q_{\mathrm{e}}=\frac{C_{\mathrm{o}}-C_{\mathrm{e}}(V)}{w}$

where $C_{\mathrm{o}}$ is the initial metal ion concentration in solution $(\mathrm{mg} / \mathrm{L}), C_{\mathrm{e}}$ is the equilibrium concentration of the adsorbate $(\mathrm{mg} / \mathrm{L}), V$ is the volume of solution $(\mathrm{L})$ and $w$ is the weight of adsorbent used $(\mathrm{g})$.

The removal percentage $(E \%)$ was calculated according to the equation below:

$E=\frac{C_{\mathrm{o}}-C_{\mathrm{e}}}{C_{\mathrm{o}}} \times 100$

where $q_{\mathrm{e}}(\mathrm{mg} / \mathrm{g})$ is the amount of metal ion adsorbed on the adsorbent, $C_{\mathrm{o}}$ is the initial metal ion concentration $(\mathrm{mg} / \mathrm{L})$, $C_{\mathrm{e}}$ is the equilibrium concentration of metal ion $(\mathrm{mg} / \mathrm{L}), \mathrm{V}$ is the volume of metal ion solution used $(\mathrm{mL}), \mathrm{W}$ is the weight of adsorbent used $(\mathrm{g})$ and $\mathrm{E}$ is the removal percentage (\%). Experiments were carried out in duplicate, and averages of the values were used for further data analysis.

Equilibrium data were fitted to the Langmuir and Freundlich models, while kinetic data were fitted to the pseudo-first-order, pseudo-second-order, Elovich, double exponential, intraparticle diffusion and Brouers-WeronSotolongo (BWS) kinetic models. The discussions on the theory of equilibrium and kinetic models used in this study are in the supplementary document (Appendix 2). All model analyses were done using KyPlot version 2.0 software in the quasi-Newton (least square) mode.

\section{Results and discussion}

\section{Physicochemical properties of adsorbent}

Figure 1 shows the Fourier transform infrared spectra of both unmodified and modified kaolinite, respectively. The band assignments of the infrared spectrum of $5 \%$ GHAmodified kaolinite clay adsorbent are shown in Table 1 . The adsorption band at 3700,3619 and $3394 \mathrm{~cm}^{-1}$ for unmodified clay shows the presence of inner surface $-\mathrm{OH}$ stretching vibrations from the octahedral surface of the clay layers, while those at 1026, 914 and $772 \mathrm{~cm}^{-1}$ represent the $\mathrm{Si}-\mathrm{O}, \mathrm{Al}-\mathrm{OH}$ bending vibrations and $\mathrm{Si}-\mathrm{O}$ stretching, respectively (Adebowale et al. 2006; Jiang et al. 2009). The adsorption bands at $1615 \mathrm{~cm}^{-1}$ represent $-\mathrm{OH}$ bending vibration of water molecule (Jiang et al. 2009). On modification with a mixture of goethite and humic acid, the $3619 \mathrm{~cm}^{-1}$ band shifted significantly to $3445 \mathrm{~cm}^{-1}$ assigned to the stretching vibrations of free $-\mathrm{OH}$ from the mixture suggesting that the mixture would have interacted with the surface of the clay via this site. A new peak at $3125 \mathrm{~cm}^{-1}$ assigned to $\mathrm{C}-\mathrm{H}$ stretching of alkenes is probably from the humic acid portion of the mixture on the clay surface. It is observed that with the adsorption of metal ions, the peaks at around 3440 and $1030 \mathrm{~cm}^{-1}$ became broad even though there were no significant shifts in these peaks. This indicates an interaction between the metal ions and the modified material (Olu-Owolabi et al. 2010). With modification of the kaolinite clay with a binary of goethite and humic acid, cation exchange capacity of the clay increase from $7.81 \mathrm{meq} / 100 \mathrm{~g}$ to $40 \mathrm{meq} / 100 \mathrm{~g}$ while the specific surface area $\left(13 \mathrm{~m}^{2} / \mathrm{g}\right)$ was the same as that reported by Adebowale et al. (2006). This increase in CEC might be as result of the humic acid portion of the mixture which have been shown by Saito et al. (2004) to mask the charges of geothite and increase overall negative charges on the surface of a geothite-humic acid mixture.

\section{Effect of pH}

\section{Single metal system}

Figure 2 shows the plot for the adsorption of the metal ions onto GHA-modified kaolinite clay adsorbent for a Single metal system at various pHs. In this system, the adsorption of the five metal ions increases gradually with increase in $\mathrm{pH}$. The optimum uptake of metal ions was at $\mathrm{pH} 6.0$ for $\mathrm{Pb}^{2+}(96 \%)$ and $\mathrm{Cu}^{2+}(80 \%)$; $\mathrm{pH} 5.0$ for $\mathrm{Cd}^{2+}(42 \%)$; and $\mathrm{pH} 7.0$ for $\mathrm{Ni}^{2+}(79 \%)$ and $\mathrm{Zn}^{2+}(13 \%)$. The lowest uptake for all the five metals is observed at $\mathrm{pH}<4.0$. At $\mathrm{pH}>6.0$, and there is a decrease in the percentage of $\mathrm{Pb}^{2+}$ ion adsorbed on the adsorbent from $96 \%$ to $82 \%$. For the adsorption of $\mathrm{Cd}^{2+}$ and $\mathrm{Cu}^{2+}$, a plateau is observed between $\mathrm{pH}$ 5.0-6.0, after which there is a rapid increase in the percentage of $\mathrm{Cd}^{2+}$ and $\mathrm{Cu}^{2+}$ adsorbed. This rapid increase might be an indication of the precipitation of the metal hydroxide. The low adsorption of metal ions at low $\mathrm{pH}$ may be attributed to increase in the positive charge (protons, H) density on the surface sites. This results in electrostatic repulsion between the metal ions and the edge groups with positive charges $\left(\mathrm{Si}-\mathrm{OH}^{2+}\right)$ on the surface of the kaolinite clay as well as other functional groups present on the modified adsorbent. At high $\mathrm{pH}$ values $(\mathrm{pH}>6.0)$, the surface of the adsorbent becomes negatively charged and the electrostatic repulsion decreases resulting in an increase in metal ion adsorption (Taty-Costodes et al. 2003) via a mechanism similar to ion exchange interaction (Jiang et al. 2009).

\section{Quinary metal system}

Figure 3 shows the plot for the adsorption of the various metal ions onto GHA-modified kaolinite adsorbent at various pHs in a Quinary metal ion system. The amount of metal ions adsorbed on GHA-modified kaolinite adsorbent increases slowly up to $\mathrm{pH} 6.0$ for $\mathrm{Pb}^{2+}, \mathrm{Ni}^{2+}$ and $\mathrm{Cu}^{2+}$ ions and up to $\mathrm{pH} 7.0$ for $\mathrm{Cd}^{2+}$ and $\mathrm{Zn}^{2+}$ ions after which there 
Fig. 1 Fourier transformed infrared spectra for kaolinite, goethite-humic acid-modified kaolinite and metal-goethitehumic acid-modified kaolinite

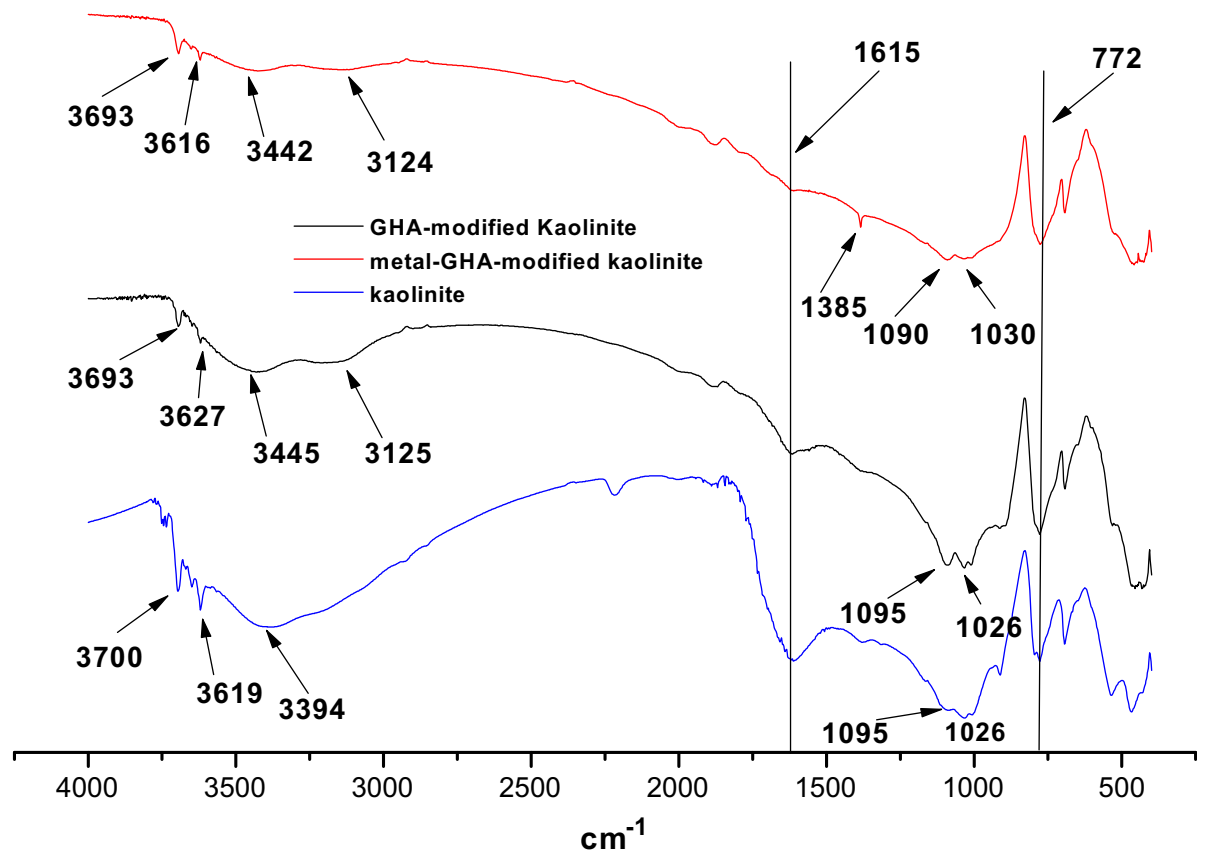

Table 1 Various kinetic data for the adsorption of $\mathrm{Pb}^{2+}, \mathrm{Cd}^{2+}, \mathrm{Zn}^{2+}, \mathrm{Ni}^{2+}$ and $\mathrm{Cu}^{2+}$ onto GHA-modified kaolinite clay

\begin{tabular}{|c|c|c|c|c|c|c|c|c|c|c|c|c|c|c|}
\hline \multicolumn{4}{|c|}{ PSOM } & \multicolumn{3}{|c|}{ ELOVICH } & \multicolumn{3}{|c|}{ DCM } & \multicolumn{3}{|c|}{ PFOM } & \multicolumn{2}{|l|}{ BSW } \\
\hline & $h$ & $k_{2}$ & $r^{2}$ & $\alpha$ & $\beta$ & $r^{2}$ & $K_{\mathrm{d}}$ & $q_{\mathrm{e}}$ & $r^{2}$ & $q_{\mathrm{e}}$ & $k_{1}$ & $r^{2}$ & $n$ & $r^{2}$ \\
\hline \multicolumn{15}{|c|}{ Single metal ion system } \\
\hline $\mathrm{Pb}$ & 0.46 & $7.1 \times 10^{-3}$ & 0.98 & 1.33 & 0.96 & 0.99 & 0.45 & 8.01 & 0.98 & 7.20 & $4.2 \times 10^{-2}$ & 0.95 & 1.14 & 0.99 \\
\hline $\mathrm{Cd}$ & 0.31 & $1.3 \times 10^{-2}$ & 0.95 & 0.77 & 2.06 & 0.98 & 0.30 & 4.79 & 0.95 & 4.28 & $4.9 \times 10^{-2}$ & 0.88 & 1.03 & 0.99 \\
\hline $\mathrm{Zn}$ & 0.31 & $6.7 \times 10^{-2}$ & 0.89 & 0.26 & 76.63 & 0.94 & 0.31 & 2.15 & 0.89 & 1.96 & $1.1 \times 10^{-1}$ & 0.83 & 1.07 & 0.94 \\
\hline $\mathrm{Ni}$ & 0.23 & $1.0 \times 10^{-2}$ & 0.97 & 0.81 & 1.28 & 0.99 & 0.24 & 4.80 & 0.97 & 4.30 & $4.0 \times 10^{-2}$ & 0.93 & 1.02 & 0.99 \\
\hline $\mathrm{Cu}$ & 0.68 & $2.1 \times 10^{-2}$ & 0.99 & 0.69 & 22.31 & 0.99 & 0.68 & 5.70 & 0.99 & 5.29 & $7.7 \times 10^{-2}$ & 0.97 & 1.09 & 0.99 \\
\hline \multicolumn{15}{|c|}{ Quinary metal ion system } \\
\hline $\mathrm{Pb}$ & 0.04 & $9.5 \times 10^{-3}$ & 0.99 & 0.30 & 3.07 & 0.91 & 0.04 & 2.09 & 0.99 & 1.63 & $2.1 \times 10^{-2}$ & 0.99 & 1.10 & 0.99 \\
\hline $\mathrm{Cd}$ & 0.18 & $4.7 \times 10^{-2}$ & 0.99 & 0.34 & 0.41 & 0.97 & 0.02 & 1.98 & 0.99 & 1.32 & $1.3 \times 10^{-2}$ & 0.99 & 1.01 & 0.99 \\
\hline $\mathrm{Zn}$ & 0.15 & $1.4 \times 10^{-2}$ & 0.98 & 0.71 & 0.65 & 0.98 & 0.15 & 3.30 & 0.98 & 2.72 & $4.0 \times 10^{-2}$ & 0.97 & 1.00 & 0.99 \\
\hline $\mathrm{Ni}$ & 0.02 & $2.7 \times 10^{-2}$ & 0.99 & 0.20 & 1.16 & 0.99 & 0.02 & 0.88 & 0.99 & 0.67 & $2.6 \times 10^{-2}$ & 0.99 & 1.01 & 0.99 \\
\hline $\mathrm{Cu}$ & 0.30 & $5.4 \times 10^{-2}$ & 0.95 & 0.34 & 8.58 & 0.98 & 0.23 & 2.06 & 0.95 & 1.81 & $8.3 \times 10^{-2}$ & 0.91 & 1.01 & 0.99 \\
\hline
\end{tabular}

PSOM pseudo-second-order model, DCM diffusion-chemisorption model, PFOM pseudo-first-order model, $B S W$ Brouers, Weron and Sotolongo model, $h\left(\mathrm{mg} \mathrm{g}^{-1} \cdot \mathrm{min}^{-1}\right) ; k_{2}\left(\mathrm{~g} \cdot \mathrm{mg}^{-1} \cdot \min \right) ; k_{1}\left(\min ^{-1}\right) ; K_{\mathrm{d}}\left(\mathrm{mg}^{-\mathrm{g}^{-1}} \cdot \mathrm{t}^{0.5}\right) ; q_{\mathrm{e}}\left(\mathrm{mg} \mathrm{g}^{-1}\right)$

was a rapid increase in the amount of metal ion adsorbed indicating precipitation of metal hydroxide (Bayat 2002). When $\mathrm{pH}$ is increased from 3.0 to 6.0 , the amount of $\mathrm{Pb}^{2+}$, $\mathrm{Ni}^{2+}$ and $\mathrm{Cu}^{2+}$ ions increases from $32 \%$ to $52 \%, 6.7 \%$ to $23 \%$ and $26 \%$ to $37 \%$, respectively, while that of $\mathrm{Cd}^{2+}$ and $\mathrm{Zn}^{2+}$ increases from $1.5 \%$ to $17.5 \%$ and $30 \%$ to $39 \%$ with $\mathrm{pH}$ increase from 3.0 to 7.0 .

In comparison with the Single metal ion system, the equilibrium capacity of the adsorbent for $\mathrm{Pb}^{2+}$ in a Quinary metal ion system reduced from 96 to $52 \%$ at $\mathrm{pH} 6.0,42$ to 13 and 78 to $17 \%$ respectively at $\mathrm{pH} 5.0$ for $\mathrm{Cd}^{2+}$ and
$\mathrm{Cu}^{2+}$, and 79 to $44 \%$ at $\mathrm{pH} 7.0$ for $\mathrm{Ni}^{2+}$. However, the removal of $\mathrm{Zn}^{2+}$ ion by GHA-modified adsorbent from aqueous solution increased from 12.79 to $35.18 \%$ at pH 6.0. The decrease in the percentage of adsorbed metal ions may be due to competition between the metal ions for adsorption sites which depends on the affinity of the adsorbent for the metal ions. The presence of co-ions enhanced the uptake of $\mathrm{Zn}^{2+}$ ions. A plateau was observed for $\mathrm{Cu}^{2+}$ ions only between $\mathrm{pH} 3.0-4.0$. In order to prevent metal hydroxide precipitation during the adsorption process, $\mathrm{pH} 5.5$ was chosen for further studies. 


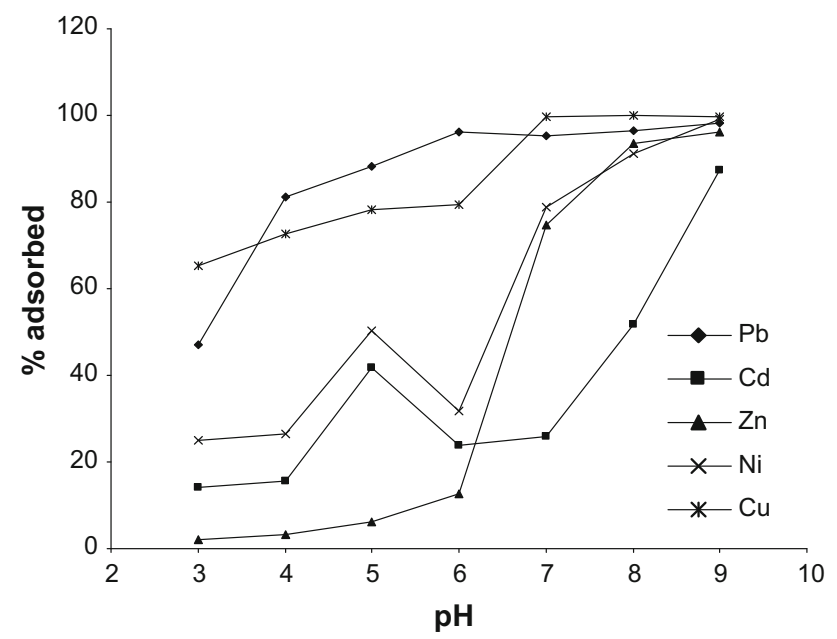

Fig. $2 \mathrm{pH}$ plot for the adsorption of $\mathrm{Pb}^{2+}, \mathrm{Cd}^{2+}, \mathrm{Zn}^{2+}, \mathrm{Ni}^{2+}$ and $\mathrm{Cu}^{2+}$ onto $5 \%$ GHA-modified kaolinite clay in Single metal system

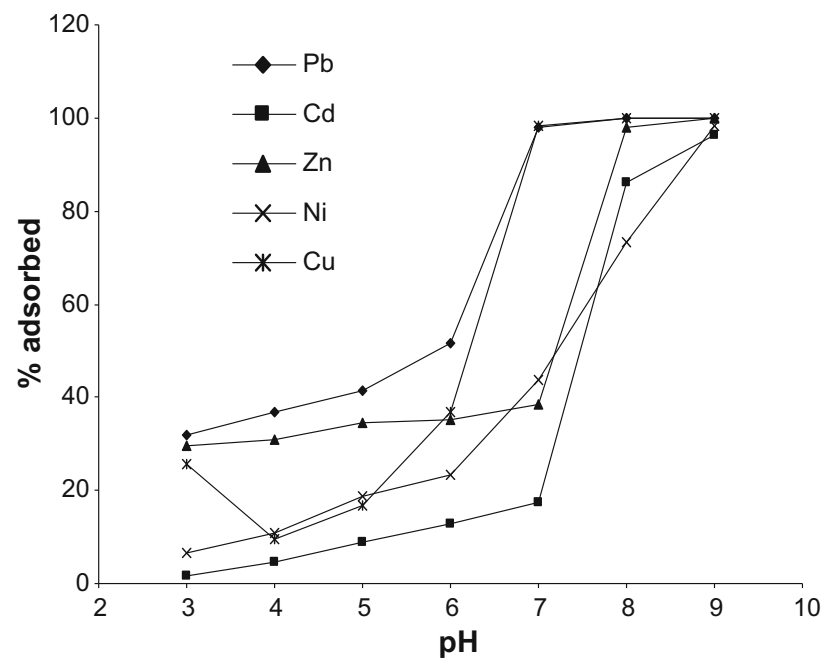

Fig. $3 \mathrm{pH}$ plot for the adsorption of $\mathrm{Pb}^{2+}, \mathrm{Cd}^{2+}, \mathrm{Zn}^{2+}, \mathrm{Ni}^{2+}$ and $\mathrm{Cu}^{2+}$ onto $5 \%$ GHA-modified kaolinite clay in Quinary metal system

\section{Effects of adsorbent dosage}

From experimental data, increase in adsorbent dose increased the amount of metal ions adsorbed for all five metal ions and in both Single and Quinary metal ion systems. However, above $0.1 \mathrm{~g}$ of the adsorbent, the percentage of $\mathrm{Pb}^{2+}$ removed from aqueous solution remain almost constant irrespective of the increase in adsorbent weight (see Figs. A1 and A2 in Appendix 3 supplementary information for plots).

The increase in the percentage of metal ion adsorbed with increase in the weight of the adsorbent may be attributed to increase in the number of available binding sites (i.e., increase in surface negative charge) and decrease in the electrostatic potential near the solid surface which favors sorbent-solute interaction.

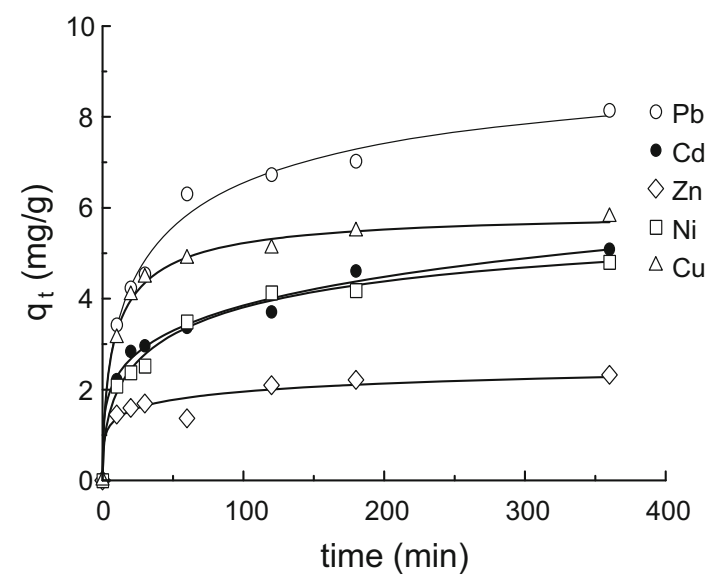

Fig. $4 \operatorname{BSW}(n, \alpha)$ kinetic modeling of metal ion adsorption GHAmodified kaolinite (Single metal system)

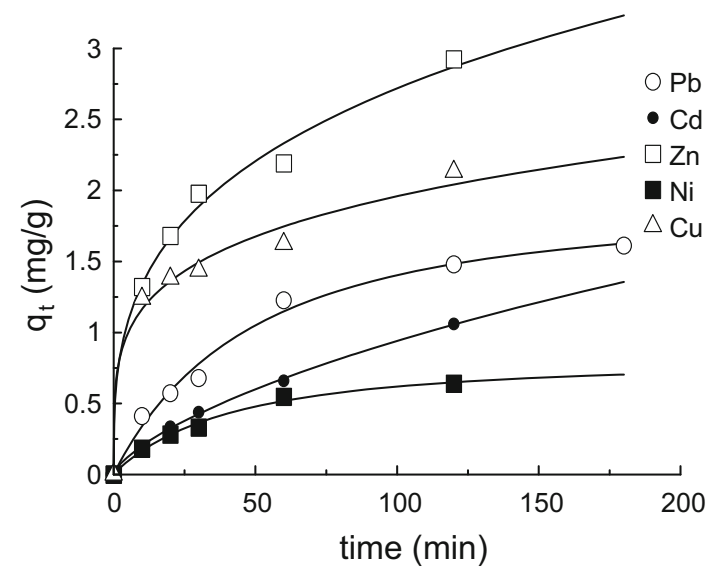

Fig. $5 \operatorname{BSW}(n, \alpha)$ kinetic modeling of metal ion adsorption GHAmodified kaolinite (Quinary metal system)

On the other hand, an increase in the adsorbent weight in aqueous solution produced a remarkable decrease in the adsorption capacity of GHA-modified kaolinite adsorbent (plots not shown). However, the equilibrium adsorption capacity of GHA-modified kaolinite adsorbent for all the metal ions investigated in our study was found to be lower in the Quinary metal ion system than in the Single metal ion system. The reduction in the adsorption capacity of the adsorbent is an evidence of competition between the metal ions for limited number of available binding sites on the GHA-modified kaolinite clay adsorbent.

\section{Kinetic studies}

The various parameters in kinetic models used in studying kinetic data obtained are shown in Table 1. The BWS fractal kinetic model (Gaspard et al. 2006) used to describe very complex adsorption systems provides better fit to 
Fig. 6 Three-dimensional plot of BWS fractal kinetic model predicted adsorption capacity $\left(q_{\mathrm{m}}\right)$ and half-life $\left(\tau_{1 / 2}\right)$ of adsorption of $\mathrm{Pb}^{2+}, \mathrm{Cd}^{2+}, \mathrm{Zn}^{2+}$, $\mathrm{Ni}^{2+}$ and $\mathrm{Cu}^{2+}$ onto GHAmodified kaolinite clay in both Single and Quinary metal ion systems

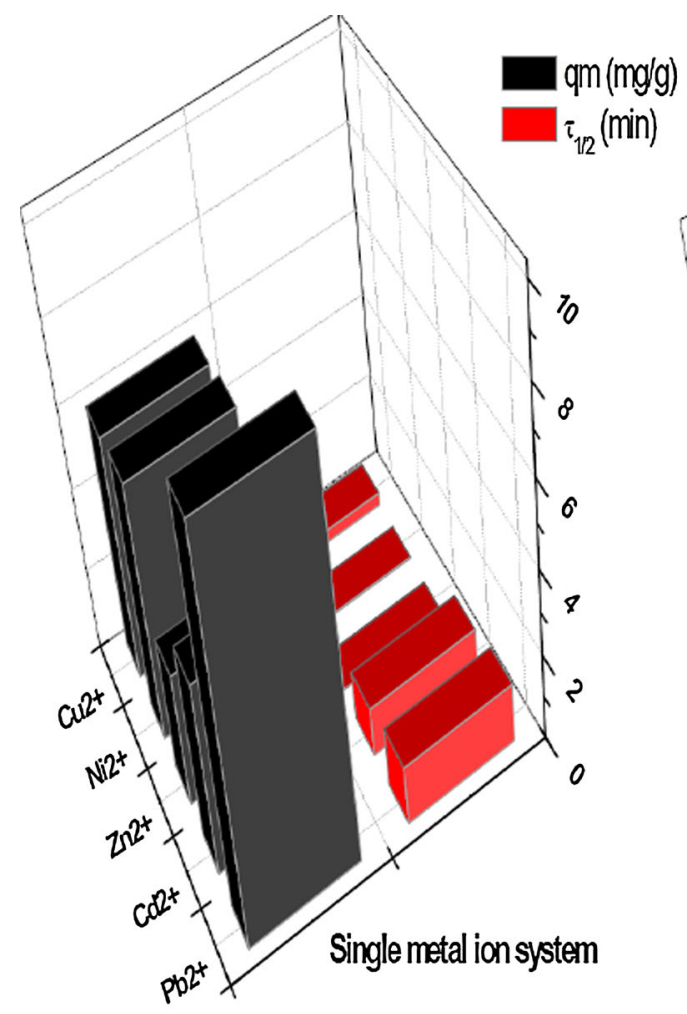

experimental data from both Single and Quinary metal ion systems than other kinetic models based on the $r^{2}$ values obtained from the nonlinear regression modeling (Figs. 4, 5) of experimental data with the various kinetic models (Table 1). Furthermore, the values of $n$ in the BSW kinetic model data suggest that the adsorption of the metal ions in both metal ion systems followed the pseudo-first-order reactions mechanism implying that the rate of adsorption of these metal ions by GHA-modified kaolinite is influenced largely by its adsorption capacity and diffusion (Ho 2006). The half-life data (Fig. 6) indicate a kinetically fast adsorption reaction in both metal ion systems that reach half its equilibrium in less than $2 \mathrm{~min}$. With the pseudosecond-order (PSO) kinetic model, experimental data from the Quinary metal ion system suggest that the initial adsorption rate $(h)$ for the metal ions onto GHA-modified kaolinite decreased, while the overall kinetic rate for the adsorption process increased when compared with data from the Single metal ion system. This situation is induced by competition for adsorption sites by the metal ions which eventually results in decreased adsorption capacity of the GHA-modified kaolinite. This implies that there are fewer available adsorption sites for each metal ion in solution and thus increased overall adsorption time. Appendices 4 and 5 in the supporting document show the various kinetic model plots (except for BSW Fractal kinetic model) for the adsorption of $\mathrm{Pb}^{2+}, \mathrm{Cd}^{2+}, \mathrm{Zn}^{2+}, \mathrm{Ni}^{2+}$ and $\mathrm{Cu}^{2+}$ in both metal ion systems.
Conversely, the overall pseudo-first-order kinetic rate constant $k_{1}$ for the adsorption of the metal ions decreased in the Quinary systems (Table 1). However, the trend for the initial sorption rate as reflected by the pseudo-second-order kinetic model was also replicated by rate constants $\alpha, K_{\mathrm{d}}$ and $k_{1}$ in Elovich, diffusion-chemisorption and pseudofirst-order kinetic models, respectively, suggesting that the adsorption of these metal ions onto GHA-modified kaolinite may also involve other mechanisms of adsorption like chemisorption even though it is predicted to be mainly diffusion controlled. The extent of heavy metal ion coverage of GHA-modified kaolinite clay as depicted by the $\beta$ constant in the Elovich model portray reduced concentration of the individual metal ions on the modified kaolinite adsorbent in the Quinary metal ion system as compared with the Single metal ion system. This is occasioned by competition among the metal ions for available adsorption sites on the surface of the adsorbent while in the Quinary metal ion system.

From PSO kinetic model, the overall kinetic rate of adsorption of $\mathrm{Pb}^{2+}$ is least in both metal ion systems, while those of $\mathrm{Zn}^{2+}$ and $\mathrm{Cu}^{2+}$ are the highest for Single and Quinary metal ion systems, respectively (Table 1). The initial sorption rate, $h$, is highest for $\mathrm{Cu}^{2+}$ and least for $\mathrm{Ni}^{2+}$ in both metal ion systems. The trend for $h$ in Single metal ion system as seen in Table $1\left(\mathrm{Cu}^{2+}>\mathrm{Pb}^{2+}>\mathrm{Cd}^{2+} \approx\right.$ $\left.\mathrm{Zn}^{2+}>\mathrm{Ni}^{2+}\right)$ is well described by their diffusion coefficients $\left(\mathrm{Cu}^{2+}=1.03, \mathrm{~Pb}^{2+}=0.9, \mathrm{Cd}^{2+}=0.7, \mathrm{Zn}^{2+}=0.7\right.$ 
and $\mathrm{Ni}^{2+}=0.7 \Delta+10^{5} \mathrm{~cm}^{2} \mathrm{~s}^{-1}$ ) (Ricordel et al. 2001; Zhao et al. 2013) except for $\mathrm{Ni}^{2+}$. However, in the Quinary metal ion system, the trend is distorted $\left(\mathrm{Cu}^{2+}>\mathrm{Cd}^{2+}>\right.$ $\mathrm{Zn}^{2+}>\mathrm{Pb}^{2+} \approx \mathrm{Ni}^{2+}$ ) and does not fit any particular trend in relation to ionic radius, ionic mobility, hydration energy or diffusion coefficient of the metal ions.

\section{Equilibrium studies}

Figure 7 shows the nonlinear Langmuir, Freundlich, twosite Langmuir and Langmuir-Freundlich model plots for the adsorption of the various metal ions by GHA-modified kaolinite, and Table 2 shows the equilibrium data obtained from Langmuir-Freundlich model plots for the adsorption. Data from other equilibrium models have been excluded from the table because they clearly showed that these other models were not suitable for describing equilibrium data obtained in this study. Using regression coefficients and error values, it is observed that the Langmuir-Freundlich model, which combines the features of Langmuir and Freundlich, provides a better fit to data in both Single and Quinary metal ion systems (Table 2 and Tables A1-A3 Appendix 6, Supplementary Information). This clearly suggest that the surface of GHA-modified kaolinite adsorbent is likely to be heterogeneous in nature (Akpa and Unuabonah 2011) and a single mechanism will not be appropriate to describe the mechanism of adsorption of these metal ions by the adsorbent. This supports our earlier deductions from kinetic data. Furthermore, the LangmuirFreundlich model fitting predicts that the GHA-modified kaolinite shows a stronger preference for $\mathrm{Pb}^{2+}$ than for other metal ions in the Quinary metal ion system and $\mathrm{Cd}^{2+}$ and $\mathrm{Ni}^{2+}$ in the Single metal ion system. The trend of metal ion preference shown by GHA-modified kaolinite in the Quinary metal ion system based on its adsorption capacity $\left(\mathrm{K}_{\mathrm{LF}}\right)$ is $\mathrm{Pb}^{2+}>\mathrm{Cu}^{2+}>\mathrm{Zn}^{2+}>\mathrm{Cd}^{2+}>\mathrm{Ni}^{2+}$ (Table 2). The predicted sequence does not exactly follow the order for the ionic radius, ionic mobility, hydration energy or diffusion coefficient values of these metal ions. For example, it is expected that the trend should be $\mathrm{Pb}^{2+}>$ $\mathrm{Zn}^{2+}>\mathrm{Cu}^{2+}>\mathrm{Ni}^{2+}>\mathrm{Cd}^{2+}$ going by their hydration energies $\quad\left(\mathrm{Pb}^{2+}=362, \quad \mathrm{Cu}^{2+}=507, \quad \mathrm{Zn}^{2+}=497\right.$, $\mathrm{Cd}^{2+}=539, \mathrm{Ni}^{2+}=511 \mathrm{kcal} / \mathrm{ion}_{\text {ion }}^{-1}$ ) as provided by Ricordel et al. (2001) and Zhao et al. (2013). The strong preference for $\mathrm{Pb}^{2+}$ exhibited by GHA-modified kaolinite is possibly due to the ease of this metal ion to loose its hydration shell and be adsorbed as compared with other metal ions with higher hydration shell energies (Unuabonah et al. 2013). The Jahn-Teller effect makes the adsorption capacity of the modified adsorbent for $\mathrm{Cu}^{2+}$ higher than that for $\mathrm{Zn}^{2+}$ and thus switches their positions in the traditional trend based on their hydration energies (Zhao et al. 2013). The variable coordination number of
Fig. 7 Nonlinear equilibrium model plots for the adsorption of metal ions onto GHA-modified kaolinite from Single metal ion system a Langmuir, b Freundlich, c two-site Langmuir and d LangmuirFreundlich model plots; from Quinary metal ion system, e Langmuir, f Freundlich, $\mathbf{g}$ two-site Langmuir and $\mathbf{h}$ Langmuir-Freundlich model plots

$\mathrm{Cd}^{2+}$ ranging from 2 to 8 (Anderson 1981) could possibly have increased its chances of being more preferred for adsorption by GHA-modified kaolinite in a Quinary metal ion system than $\mathrm{Ni}^{2+}$ which basically has a coordination number of 4 and a tetrahedral geometry (Myers 1981). Similar trend has been reported by Jalali and Moradi (2013).

There are three types of interactive adsorption behavior, viz synergism, antagonism or non-interaction. With synergism, the effect of the mixture is greater than the sum of each of the individual effects of the constituents in the mixture. With antagonism, the effect of the mixture is less than that of the sum of the individual effects of the constituents in the mixture. With non-interaction, the effect of the mixture is equivalent to the sum of each of the individual effects of the constituents in mixture (Qi and Aldrich 2008). Since the ratio of $\mathrm{K}_{\mathrm{LF}(\mathrm{Q})} / \mathrm{K}_{\mathrm{LF}(\mathrm{S})}$ for $\mathrm{Pb}^{2+}$, $\mathrm{Cd}^{2+}$ and $\mathrm{Ni}^{2+}$ is lesser than unity as shown in Table 3 , it is plausible to suggest that the presence of $\mathrm{Zn}^{2+}$ and $\mathrm{Cu}^{2+}$ in solution could exert an antagonistic effect on their adsorption by GHA-modified kaolinite. In same vein, the presence of $\mathrm{Pb}^{2+}, \mathrm{Cd}^{2+}$ and $\mathrm{Ni}^{2+}$ in solution could exert a synergistic effect on the adsorption of $\mathrm{Zn}^{2+}$ and $\mathrm{Cu}^{2+}$ ions since the ratio of $\mathrm{K}_{\mathrm{LF}(\mathrm{Q})} / \mathrm{K}_{\mathrm{LF}(\mathrm{S})}$ for these metal ions is greater than unity (Table 3 ).

\section{Effect of temperature}

Table 4 shows the thermodynamic parameters obtained from equilibrium data at various temperatures. Results from Table 4 suggest that adsorption of metal ions $\left(\mathrm{Pb}^{2+}\right.$, $\mathrm{Cd}^{2+}, \mathrm{Zn}^{2+}, \mathrm{Ni}^{2+}$ and $\mathrm{Cu}^{2+}$ ) in both Single and Quinary metal ion systems by GHA-modified kaolinite was endothermic $\left(+\Delta H_{\mathrm{ad}}\right)$ and the complex formed between the adsorbate and adsorbent as predicted by $\Delta S_{\text {ad }}$ was stable with increasing temperature. However, in the Quinary metal ion system, the adsorption process is less endothermic and complex formed between adsorbent and adsorbate is predicted to be less stable (Table 4). This could be inferred from the fact that in a Quinary metal system, since adsorption capacity of the adsorbent decreases for each of the metal ion, the heat of adsorption, $\Delta H_{\text {ad }}$, will also decrease.

The magnitude of the adsorption enthalpy, $\Delta H_{\mathrm{ad}}$, indicates weak bonding between the metal ions and the clay minerals (Bhattacharyya and Gupta 2011). The sign and magnitude of $\Delta H_{\text {ad }}$ can be used to provide 

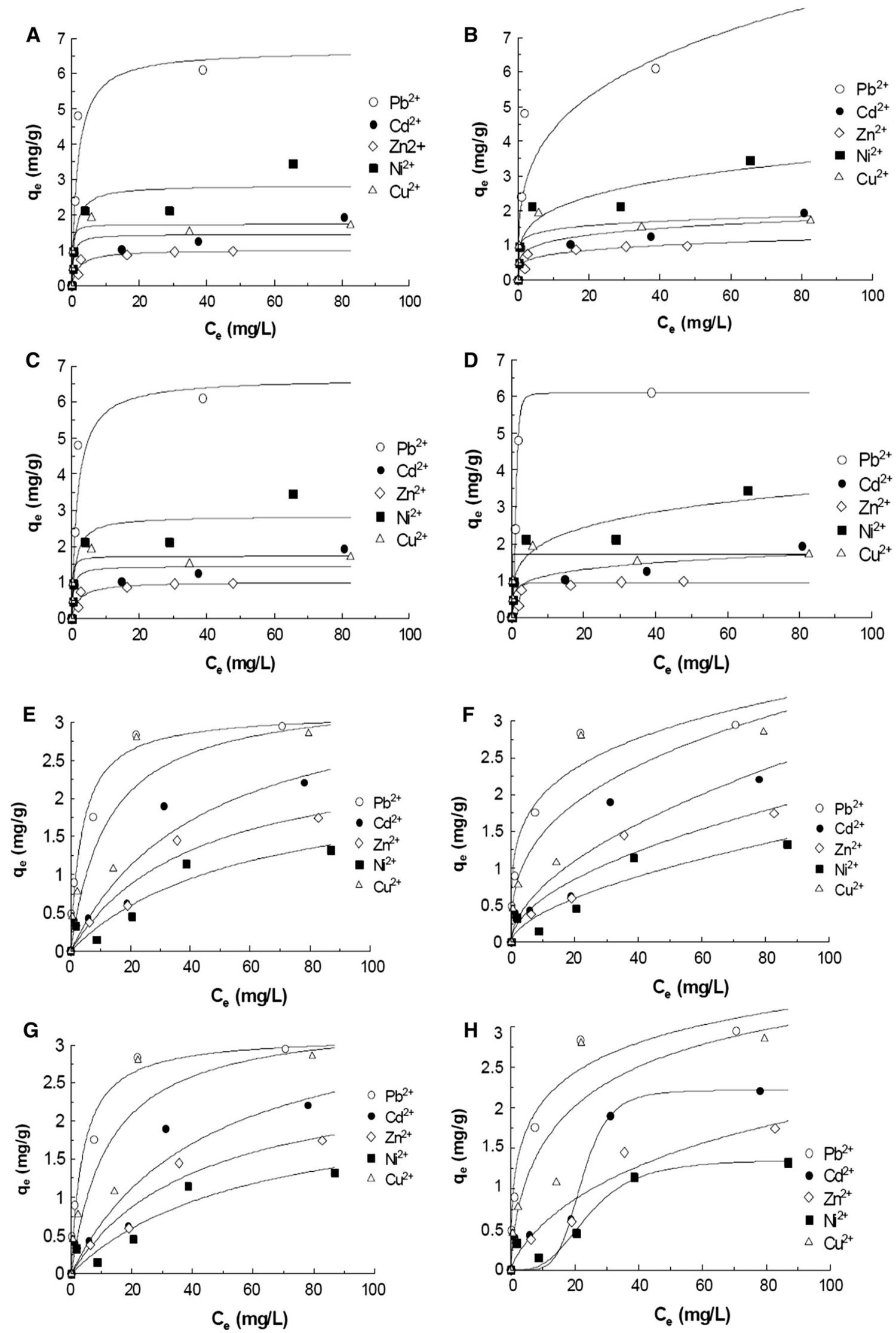
Table 2 Predicted data from Langmuir-Freundlich isotherm model for the adsorption of metal ions onto $5 \%$ GHA-modified kaolinite clay

\begin{tabular}{lcclll}
\hline & $k_{\mathrm{LF}}\left(\mathrm{mg}^{1-(1 / n)} \mathrm{L}^{1 / n} / \mathrm{g}\right)$ & $b_{\mathrm{LF}}(\mathrm{L} / \mathrm{g})$ & $n$ & $r^{2}$ & Error \\
\hline \multicolumn{2}{l}{ Single metal ion system } \\
$\mathrm{Pb}$ & 6.10 & 3.04 & 0.90 & 0.9845 & 0.16 \\
$\mathrm{Cd}$ & 13.85 & 0.21 & $5.9 \times 10^{-7}$ & 0.8868 & 0.08 \\
$\mathrm{Zn}$ & 0.93 & 6.20 & 0.47 & 0.9915 & 0.002 \\
$\mathrm{Ni}$ & 13.89 & 0.28 & $2.2 \times 10^{-4}$ & 0.9097 & 0.25 \\
$\mathrm{Cu}$ & 1.71 & 17.79 & 6.78 & 0.9707 & 0.03 \\
$\mathrm{Quinary} \mathrm{metal} \mathrm{ion} \mathrm{system}$ & & & & \\
$\mathrm{Pb}$ & 5.58 & 0.39 & 0.025 & 0.9619 & 0.10 \\
$\mathrm{Cd}$ & 2.22 & 5.34 & 0.045 & 0.9152 & 0.12 \\
$\mathrm{Zn}$ & 3.97 & 0.76 & 0.010 & 0.9340 & 0.05 \\
$\mathrm{Ni}$ & 1.37 & 3.24 & 0.041 & 0.9172 & 0.04 \\
$\mathrm{Cu}$ & 4.37 & 0.65 & 0.039 & 0.8611 & 0.34 \\
\hline
\end{tabular}

Table 3 Ratio of adsorption capacity $\left(\mathrm{q}_{\mathrm{e}(\text { mix })} / \mathrm{q}_{\mathrm{e}(\text { single })}\right)$

\begin{tabular}{lcll}
\hline Metal ions & $q_{\text {e(single) }}$ & $q_{\text {e(quinary) }}$ & $q_{\text {e(quinary) }} / q_{\text {e(single })}$ \\
\hline $\mathrm{Pb}^{2+}$ & 6.10 & 5.58 & 0.91 \\
$\mathrm{Cd}^{2+}$ & 15.55 & 2.22 & 0.14 \\
$\mathrm{Zn}^{2+}$ & 0.93 & 3.97 & 4.27 \\
$\mathrm{Ni}^{2+}$ & 13.88 & 1.37 & 0.10 \\
$\mathrm{Cu}^{2+}$ & 1.71 & 4.37 & 2.56 \\
\hline
\end{tabular}

information about the adsorption reaction and mechanism of possible ligand retention. The small but positive adsorption enthalpy are strong indications that the outersphere complexation mechanism may have played a major role in the adsorption of these metal ions GHA-modified kaolinite in both Single and Quinary metal ion systems (Journey et al. 2010). This simply implies that the innersphere adsorption sites at the edges of the kaolinite reported by Srivastava et al. (2005) may have been used up for modification or possibly 'blocked' by the modifying reagent such that these cations are not able to access them. Outersphere complexation occurs via weak electrostatic bonds requiring ions existing in close proximity to one another on the surface (Journey et al. 2010). From $\Delta S_{\text {ad }}$ values in Table 3, it is predicted that $\mathrm{Pb}^{2+}$ and $\mathrm{Ni}^{2+}$ form a more stable complex with GHA-modified kaolinite in Single and Quinary metal ion systems, respectively. Adsorption of these metal ions $\left(\mathrm{Pb}^{2+}, \mathrm{Cd}^{2+}, \mathrm{Zn}^{2+}, \mathrm{Ni}^{2+}\right.$ and $\left.\mathrm{Cu}^{2+}\right)$ was observed to be fairly spontaneous $\left(-\Delta G_{\text {ad }}\right)$ in both metal ion systems with reduced spontaneity for adsorption in the Quinary metal ion system (Table 4). Increasing temperature, however, did not significantly improve the spontaneity of the adsorption of these metal ions by GHA-modified
Table 4 Thermodynamic parameters for the adsorption of $\mathrm{Pb}^{2+}$, $\mathrm{Cd}^{2+}, \mathrm{Zn}^{2+}, \mathrm{Ni}^{2+}$ and $\mathrm{Cu}^{2+}$ onto GHA-modified kaolinite clay

\begin{tabular}{|c|c|c|c|c|c|c|c|}
\hline & \multirow[t]{2}{*}{$+\Delta H_{\mathrm{ad}}$} & \multirow[t]{2}{*}{$+\Delta S_{\mathrm{ad}}$} & \multirow[t]{2}{*}{$r^{2}$} & \multicolumn{4}{|l|}{$-\Delta G_{\mathrm{ad}}$} \\
\hline & & & & $303 \mathrm{~K}$ & $313 \mathrm{~K}$ & $323 \mathrm{~K}$ & $333 \mathrm{~K}$ \\
\hline \multicolumn{8}{|c|}{ Single metal ion system } \\
\hline $\mathrm{Pb}^{2+}$ & 0.89 & 32.05 & 0.92 & 8.82 & 9.14 & 9.46 & 9.78 \\
\hline $\mathrm{Cd}^{2+}$ & 0.95 & 18.77 & 0.92 & 4.74 & 4.93 & 5.11 & 5.33 \\
\hline $\mathrm{Zn}^{2+}$ & 1.61 & 19.89 & 0.87 & 4.42 & 4.62 & 4.81 & 5.01 \\
\hline $\mathrm{Ni}^{2+}$ & 0.56 & 13.39 & 0.99 & 3.50 & 3.63 & 3.76 & 3.90 \\
\hline $\mathrm{Cu}^{2+}$ & 1.04 & 22.36 & 0.98 & 5.74 & 5.96 & 6.18 & 6.41 \\
\hline \multicolumn{8}{|c|}{ Quinary metal ion system } \\
\hline $\mathrm{Pb}^{2+}$ & 0.27 & 1.15 & 0.80 & 0.078 & 0.090 & 0.10 & 0.11 \\
\hline $\mathrm{Cd}^{2+}$ & 0.36 & 1.81 & 0.95 & 0.19 & 0.21 & 0.22 & 0.24 \\
\hline $\mathrm{Zn}^{2+}$ & 0.66 & 8.53 & 0.86 & 1.92 & 2.01 & 2.10 & 2.18 \\
\hline $\mathrm{Ni}^{2+}$ & 0.86 & 11.88 & 0.90 & 2.74 & 2.86 & 2.98 & 3.10 \\
\hline $\mathrm{Cu}^{2+}$ & 0.44 & 2.36 & 0.81 & 0.28 & 0.30 & 0.32 & 0.35 \\
\hline
\end{tabular}

kaolinite in both metal ion systems. The $\Delta G_{\text {ad }}$ values obtained in this study suggest that the adsorption of these metal ions by GHA-modified kaolinite in both metal ion systems is mainly diffusion-controlled transport and electrostatic (physical adsorption) since they are below $-20 \mathrm{~kJ} \mathrm{~mol}^{-1}$ (Unuabonah et al. 2007).

Entropy change, $\Delta S_{\text {ad }}$, for the adsorption process in both metal ion systems was positive within the temperature range of $303-333 \mathrm{~K}$ with values in the range of 1.15 and $32.05 \mathrm{~J} \mathrm{~K}^{-1} \mathrm{~mol}^{-1}$ (Table 4). We can thus predict that adsorption of these metal ions onto GHA-modified kaolinite adsorbent was accompanied with some structural changes in the adsorbate and adsorbents during the adsorption process from aqueous solution onto the adsorbents (Unuabonah et al. 2007; Bhattacharyya and Gupta 2011).

The magnitude of the thermodynamic parameters obtained in this study is quite low compared with those obtained in reports by Yavuz et al. (2003), Echeverria et al. (2003), Gupta and Bhattacharyya (2008) and Bhattacharyya and Gupta (2009) for the adsorption of $\mathrm{Pb}^{2+}$, $\mathrm{Cd}^{2+}, \mathrm{Ni}^{2+}$ and $\mathrm{Cu}^{2+}$. Given our earlier discussions on the kinetic data of the adsorption of these metal ions by GHAmodified kaolinite adsorbent, it is possible to suggest that the adsorption process in both metal ion systems is more kinetically driven (by diffusion-controlled transport) than it is thermodynamically.

\section{Conclusion}

The competitive adsorption of $\mathrm{Pb}^{2+}, \mathrm{Cd}^{2+}, \mathrm{Zn}^{2+}, \mathrm{Ni}^{2+}$ and $\mathrm{Cu}^{2+}$ in Quinary metal system onto a geothite-humic acid (GHA)-modified kaolinite was reported in this study. The 
presence of external surface $-\mathrm{OH}$ and $\mathrm{C}-\mathrm{H}$ stretch at 3445 and $3125 \mathrm{~cm}^{-1}$ from Fourier transformed infrared (FTIR) studies suggests that the modification was effective on the surface of the kaolinite clay. The surface properties of kaolinite were improved by modification with a mixture of goethite and humic acid. Adsorption capacity of GHA modified kaolinite was found to increase with increasing adsorbent weight for both single and multi-metal ion solutions with adsorption in multi-ion giving lower adsorption capacities. However, the adsorption of $\mathrm{Pb}^{2+}$ and $\mathrm{Ni}^{2+}$ was suppressed by the simultaneous presence of other metal ions. The increase in $\mathrm{pH}$ and temperature increased the adsorption capacity of GHA-modified kaolinite for heavy metal ions in both single and multi-metal ion systems, but competition for adsorption sites tends to reduce the heat of adsorption of system. Similarly, increase in adsorbent dosage reduced the adsorption capacity of GHAmodified adsorbent. The presence of $\mathrm{Zn}^{2+}$ and $\mathrm{Cu}^{2+}$ suppressed that adsorption of $\mathrm{Pb}^{2+}, \mathrm{Cd}^{2+}$ and $\mathrm{Ni}^{2+}$ with $\mathrm{Ni}^{2+}$ being the most suppressed. The Brouers-Weron-Sotolongo (BWS) fractal kinetic model predicted that the adsorption of metal ions onto GHA-modified kaolinite follow the pseudo-first order kinetic model and adsorption of the metal ion is thus predicted to be diffusion controlled in the Single metal ion system, but a combination of BWS and pseudo-second-order kinetic models predicts a combination of adsorption mechanisms with no special preference to any. From thermodynamic point of view, the adsorption of metal ions in both Single and Quinary metal systems was endothermic and spontaneous although the spontaneity of the adsorption process was well reduced in the Quinary metal system. Change in temperature did not improve the spontaneity of the adsorption process in both metal systems significantly.

Acknowledgments The authors appreciate with thanks the Department of Chemistry, University of Ibadan and the Department of Chemical Sciences, Redeemer's University for provision of Laboratory space and scientific equipment for this research.

\section{References}

Adebowale KO, Unuabonah EI, Olu-Owolabi BI (2005) Adsorption of some heavy metal ions on sulfate- and phosphate-modified Kaolin. Appl Clay Sci 29:145-148

Adebowale KO, Unuabonah EI, Olu-Owolabi BI (2006) The effect of some operating variables in the adsorption of lead and cadmium ions unto modified Kaolin clay. J Hazard Mater B134:130-139

Akpa OM, Unuabonah EI (2011) Small-sample corrected Akaike information criterion: an appropriate statistical tool for ranking of adsorption isotherm models. Desalination 272(1-3):20-26

Alekseeva TV, Zolotareva BN (2013) Fractionation of humic acids upon adsorption on Montmorillonite and Palygorskite. Eurasian Soil Sci 46:622-634
Aliyu AA, Aluko BA, Biliaminu KO (1996) Priority investment projects in the solid minerals sector. Raw materials Research and Development Council, Abuja, pp 12-14

Anderson O (1981) Chelation of cadmium. Environ Health Perspect $54: 249-266$

Apak R (2002) Adsorption of heavy metal ions on soil surfaces and similar substances. In Encyclopedia of surface \& colloid science. Marcel Dekker, New York

Backes CA, McLaren RG, Rate AW (1995) Kinetics of cadmium and cobalt desorption from Iron and manganese oxides. J Hazard Mater B95:251-273

Bayat B (2002) Comparative study of adsorption properties of Turkish fly ashes I. The case of nickel(II), copper(II) and zinc(II). J Hazard Mater B10:285-300

Bhattacharyya KG, Gupta SS (2009) Calcined tetrabutylammonium kaolinite and montmorillonite and adsorption of $\mathrm{Fe}(\mathrm{II}), \mathrm{Co}(\mathrm{II})$ and $\mathrm{Ni}(\mathrm{II})$ from solution. Appl Clay Sci 46:216-221

Bhattacharyya KG, Gupta SS (2011) Removal of $\mathrm{Cu}$ (II) by natural and acid-activated clays: an insight of adsorption isotherm, kinetic and thermodynamics. Desalination 272:66-75

Buffle J (1985) Complexation reactions in aquatic systems: an analytical approach. Ellis Horwood, Chichester

Chapman HD (1965) Cation exchange capacity. In: Black CA (ed) Methods of soil analysis Part 2. Number 9 in the series Agronomy: American Society of Agronomy, Madison, Wisconsin, p 891-901

Choppin GR (1992) The role of natural organics in Radionuclide migration in natural aquifier systems. Radiochim Acta 113:58-59

Davies JA (1982) Adsorption of natural dissolved organic matter at the oxide/water interface. Geochim Cosmochim Acta 46:2381-2393

Echeverria J, Indurain J, Churio E, Garrido J (2003) Simultaneous effect of $\mathrm{pH}$, temperature, ionic strength, and initial concentration on the retention of Ni on illite. Colloids Surf Physicochem Eng Aspects 218:175-187

Gaspard S, Altenor S, Passe-Coutrin N, Ouensanga A, Brouers F (2006) Parameters from a new kinetic equation to evaluate activated carbons efficiency for water treatment. Water Res 40:3467-3477

Gimenez J, Martinez M, de Pablo J, Rovira M, Duro L (2007) Arsenic sorption onto natural hematite, magnetite and geothite. J Hazard Mater 141:575-580

Glover LJ II, Eick MJ, Brady PV (2002) Desorption kinetics of cadmium and lead from goethite: influence of time and organic acids. Soil Sci Soc Am J 66:797-804

Grossi PR, Sparks DL (1994) Rapid kinetics of $\mathrm{Cu}(\mathrm{II})$ adsorption/ desorption on goethite. Environ Sci Technol 28:1422-1429

Gupta SS, Bhattacharyya KG (2008) Immobilization of $\mathrm{Pb}(\mathrm{II}), \mathrm{Cd}(\mathrm{II})$ and $\mathrm{Ni}$ (II) ions on Kaolinite and Montmorillonite surfaces from aqueous medium. J Environ Manag 87:46-58

Hiraide M (1992) Heavy metal complexed with humic substance in fresh water. Anal Sci 8:453-459

Ho Y-S (2006) Review of second-order models for adsorption systems. J Hazard Mater B136:681-689

Jalali M, Moradi F (2013) Competitive sorption of $\mathrm{Cd}, \mathrm{Cu}, \mathrm{Mn}, \mathrm{Ni}$, $\mathrm{Pb}$, and $\mathrm{Zn}$ in polluted and unpolluted calcacerous soils. Environ Monit Assess 185:8831-8846

Jiang M, Wang Q, Jin X, Chen Z (2009) Removal of Pb(II) from aqueous solution using modified and unmodified Kaolinite clay. J Hazard Mater 170:332-339

Journey JS, Anderson RM, Essington ME (2010) The adsorption of 2-Ketogluconate by geothite. Soil Sci Soc Am J 74:1119-1128

Jung J, Cho Y-H, Hahn P (1998) Comparative study of $\mathrm{Cu}^{2+}$ adsorption on geothite, hematite and kaolinite: mechanistic approach. Bull Korean Chem Soc 19:324-327 
Lackovic K, Angove MJ, Wells JD, Johnson BB (2003) Modelling the adsorption og $\mathrm{Cd}(\mathrm{II})$ onto Muloorina illite and related clay minerals. J Colloids Interface Sci 257:31-40

McBride MB (1994) Environmental soil chemistry. Oxford University Press, New York

McCarthy JF, Czerwinski KR, Sanford WE, Jardine PM, Marsh JD (1998) Mobilization of transuranic radionuclides from disposal trenches by natural organic matter. J Contam Hydrol 30:49-77

Myers RT (1981) Rules of coordination number of metal ions. J Chem Educ 58(9):681

Olu-Owolabi BI, Popoola DB, Unuabonah EI (2010) Removal of $\mathrm{Cu}^{2+}$ and $\mathrm{Cd}^{2+}$ from aqueous solution by Bentonite clay modified with binary mixture of goethite and humic acid. Water Air Soil Pollut 211:459-474

Plavsic M, Cosovic B, Miletic S (1991) Comparison of the behaviours of copper, cadmium and lead in the presence of humic acid in sodium chloride solutions. Anal Chim Acta 255:15-21

Qi BC, Aldrich C (2008) Adsorption of heavy metals from aqueous solutions with tobacco dust. Bioresour Technol 99:5595-5601

Ricordel S, Taha S, Cisse I, Dorange G (2001) Heavy metals removal by adsorption onto peanut husks carbon: characterization, kinetic study and modeling. Sep Purif Technol 24:389-401

Saada A, Gaboriau H, Cornu S, Bardot F, Villieras F, Croue JP (2003) Adsorption of humic acid onto a kaolinite clay studied by highresolution argon adsorption volumetry. Clay Miner 38:433-443

Saito T, Koopal LK, van Riemsdijk WH, Nagasaki S, Tanaka S (2004) Adsorption of humic acid on goethite: isotherms, charge adjustments, and potential profiles. Langmuir 20:689-700

Salman M, El-Eswed B, Khalili F (2007) Adsorption of humic acid on bentonite. Appl Clay Sci 38:51-56

Sears GW (1956) Determination of specific surface area of colloidal silica by titration with sodium hydroxide. J Anal Chem 28:1981-1983

Srivastava P, Singh B, Angove MJ (2005) Competitive adsorption behavior of heavy metals on kaolinite. J Colloids Interface Sci 290:28-38
Swift RS (1996) Organic matter characterization. In: Sparks DL, Page AL, Helmke PA, Loeppert RH, Soltanpour PN, Tabatabai MA, Johnston CT, Summer ME (eds) Methods of soil analysis: chemical methods, vol 3. Soil Science Society of America (SSSA) book series 5, p 1011-1020

Takahashi Y, Minai Y, Ambe S, Makide Y, Ambe F (1999) Comparison of adsorption behavior of multiple inorganic ions on kaolinite and silica in the presence of humic acid using the multitracer technique. Geochim Cosmochim Acta 63:815-836

Taty-Costodes VC, Faudue H, Porte C, Delacroix A (2003) Removal of $\mathrm{Cd}(\mathrm{II})$ and $\mathrm{Pb}$ (II) ions, from aqueous solutions, by adsorption onto sawdust of Pinus sylvestris. J Hazard Mater 105:121-142

Tipping E, Rey-Castro C, Bryan SE, Hamilton-Taylor J (2002) Al(III) and $\mathrm{Fe}(\mathrm{III})$ binding by humic substances in freshwaters, and implications for trace metal speciation. Geochim Cosmochim Acta 66:3211-3224

Unuabonah EI, Adebowale KO, Olu-Owolabi BI (2007) Kinetic and thermodynamic studies of the adsorption of lead(II) ions onto phosphate-modified kaolinite clay. J Hazard Mater 144:386-395

Unuabonah EI, Gunter C, Weber J, Lubahn S, Taubert A (2013) Hybrid clay: a new highly efficient Adsorbent for water treatment. ACS Sustain Chem Eng 1(8):966-973

Wang K, Xing B (2005) Structural and sorption characteristics of adsorbed humic acid on clay minerals. J Environ Qual 34:342-349

Wu J, West LJ, Stewart DI (2002) Effect of humic substances on $\mathrm{Cu}(\mathrm{II})$ solubility in kaolin-sand soil. J Hazard Mater B94:223-238

Yavuz O, Altunkaynak Y, Guzel F (2003) Removal of copper, cobalt and manganese from aqueous solution by kaolinite. Water Res 37:948-952

Zhao X-Q, Dong L-J, Cao Y, Mo S-J, Yi J-J, Xu Q-H (2013) Exfoliated LDHs modified with organic silicon reagent and their adsorption to metal ions from water. Chin $\mathrm{J}$ Inorg Chem 29(4):817-825 